\title{
PENINGKATAN HASIL BELAJAR SISWA PADA PEMBELAJARAN PKn MENGGUNAKAN MODEL STAD DI KELAS V SEKOLAH DASAR
}

\section{Oleh:}

Mona Rahmadani, Dra. Reinita, M.Pd, Dra. Tin Indrawati, M.Pd monarahmadanimona@gmail.com, reinita_reinita@yahoo.com,

indrawati_tin@yahoo.com

\begin{abstract}
Abstrak
Tujuan penelitian ini untuk mendeskripsikan peningkatan hasil belajar siswa pada pembelajaran PKn menggunakan model STAD di kelas V SD. Subjek penelitian adalah peneliti dan 20 orang siswa. Jenis penelitian adalah penelitian tindakan kelas dengan pendekatan kualitatif dan kuantitatif. Penelitian menunjukkan perencanaan mengalami peningkatan dari siklus I 76,12 menjadi 93,5 pada siklus II, aspek guru meningkat dari 68,74 pada siklus I menjadi 91,66 pada siklus II, aspek siswa dari siklus I 68,74 menjadi 91,66 pada siklus II, hasil belajar siswa dari siklus I 76,12 menjadi 93,5 pada siklus II. Dapat disimpulkan bahwa dengan menggunakan model STAD dapat meningkatkan hasil belajar siswa.
\end{abstract}

Kata Kunci: PKn, hasil belajar, model STAD

\section{Abstract}

The aim this research is to describe the improvement of students' learning result in the civic subject by using the STAD Model for $5^{\text {th }}$ grade students. The subjects of this research were the researcher herself and 20 students. This classroom action research used qualitative and quantitative approaches. The result shows that in planning phases there is improvement from 76.12 in cycle I to 93.5 in cycle II. Teachers' aspect improves from 68.74 in cycle I 91.66 in cycle II. Students' aspect improves from 68.74 in cycle to 91.66 in cycle II. Furthermore, the improvement also can be seen from students' learning result that improves from 76.12 in cycle I to 93.5 in cycle II. Thus, it can be concluded that the implementation of the STAD Model can improve students' learning result. 


\section{PENDAHULUAN}

Pendidikan Kewarganegaraan ( $\mathrm{PKn}$ ) adalah salah satu mata pelajaran yang dipelajari di Sekolah Dasar (SD). Pembelajaran PKn ini merupakan pembelajaran yang memfokuskan pada pembentukan warga negara yang memahami dan mampu melaksanakan hak dan kewajiban untuk menjadi warga negara yang cerdas, terampil, dan berkarakter yang diamanatkan oleh pancasila dan undang-undang dasar 1945 (Depdiknas, 2006:271).

Tujuan pembelajaran PKn yang dipelajari di SD bagi siswa agar siswa memiliki kemampuan untuk berpikir secara kritis, rasional, dan kreatif dalam menanggapi isu kewarganegaraan, berpartisipasi secara aktif dan bertanggung jawab, bertindak secara cerdas dalam kegiatan masyarakat, berbangsa dan bernegara serta anti korupsi, berkembang secara positif dan demokratis untuk membentuk diri berdasarkan karakter-karakter masyarakat Indonesia agar dapat hidup bersama dengan bangsa-bangsa lainnya dan dapat berintekrasi dengan bangsa lain dalam percaturan dunia secara langsung atau tidak langsung dengan memanfaatkan teknologi informasi dan komunikasi.

Ungkapan tersebut sesuai dengan yang dinyatakan Mohammad Said dalam jurnalnya yang menyatakan:

Pendidikan di Negara Kesatuan Republik Indonesia, diharapkan dapat mempersiapkan murid menjadi warga negara yang kuat dan konsisten untuk mempertahankan Negara Kesatuan Republik Indonesia. Hakekat Negara Kesatuan Republik Indonesia adalah negara kebangsaan yang modern. Negara kesatuan yang modern adalah negara yang pembentukannya didasarkan pada semangat kebangsaan atau nasionalisme yaitu pada tekad suatu masyarakat untuk membangun masa depan bersama dibawah satu cita-cita yang sama walaupun masyarakatnya berbeda suku, agama, ras, dan etnik atau golongan. Maka dari itu hal tersebut dapat dicapai dalam tujuan-tujuan pengajaran PKn.

Dalam memahami pengertian dan tujuan pembelajaran PKn tersebut, guru harus mampu membuat siswa ikut aktif dalam proses pembelajaran. Hal ini dapat dicapai dengan memanfaatkan model-model pembelajaran yang bisa digunakan dalam pembelajaran. 
Berdasarkan observasi yang dilakukan pada tanggal 12 Juli 2017 di kelas V SD Pembangunan Laboratorium UNP Kota Padang, pembelajaran PKn kurang diminati siswa. Hal ini dibuktikan dengan banyaknya nilai prites siswa yang di bawah KKM yang ditetapkan sekolah yaitu 80. Nilai pembelajaran PKn yang dibawah KKM ini disebabkan oleh berbagai faktor, diantaranya guru mengajar masih menggunakan metode ceramah, pembelajaran hanya berpusat pada guru (teacher centered), guru masih banyak menyuruh siswa menghafal materi, guru masih belum maksimal dalam menerapkan kegiatan belajar kelompok, guru masih belum maksimal dalam menerapkan model pembelajaran kooperatif yang menggunakan model dalam proses pembelajaran $\mathrm{PKn}$, siswa kurang aktif dalam kegiatan pembelajaran, siswa menganggap pembelajaran PKn pembelajaran yang membosankan dan menjenuhkan sehingga nilai ulangan siswa banyak yang rendah.

Untuk mengatasi masalah tersebut guru hendaklah dapat menciptakan suasana belajar yang menarik perhatian dan merangsang siswa untuk terlibat aktif dan tertarik dalam kegiatan pembelajaran PKn. Salah satu yang dapat dilakukan adalah melalui penggunaan model pembelajaran dalam proses pembelajaran.

Menurut Joice \& Weil (dalam Rusman 2011:133) bahwa "Model pembelajaran adalah suatu rencana atau pola yang dapat digunakan untuk membentuk kurikulum (rencana pembelajaran jangka panjang), merancang bahan-bahan pembelajaran, dan membimbing pembelajaran di kelas atau yang lain."

Cooperative Learning tipe STAD merupakan salah satu model yang dapat digunakan dalam pembelajaran PKn, karena Cooperative Learning tipe STAD dapat meningkatkan rasa tanggung jawab siswa, baik secara pribadi maupun kelompok dalam proses pembelajarannya.

Davidson (dalam Nur Asma, 2008:21) mengemukakan keunggulan atau kebaikan model pembelajaran kooperatif tipe STAD yaitu dapat meningkatkan kecakapan individu maupun kelompok, meningkatkan komitmen, menghilangkan prasangka buruk terhadap teman sebaya, tidak bersifat kompetitif dan tidak memiliki rasa dendam. Untuk itu peneliti tertarik melakukan Penelitin Tindakan Kelas (PTK) 
untuk meningkatkan hasil belajar siswa pada pembelajaran PKn menggunakan model pembelajaran STAD di kelas V SD. Tujuan penelitian ini untuk mendeskripsikan peningkatan hasil belajar siswa pada pembelajaran PKn menggunakan model STAD di kelas V SD.

\section{METODOLOGI}

Pendekatan yang digunakan dalam penelitian ini adalah pendekatan kualitatif dan kuantitatif. Pendekatan kualitatif merupakan data yang berkenaan dengan perbaikan atau peningkatan proses pembelajaran pada suatu kelas sedangkan pendekatan kuantitatif dipergunakan untuk data-data yang bersifat angka-angka. Menurut Arma Mariangke dalam jurnalnya mengatakan "Pendekatan kualitatif yaitu data yang diperoleh dari aktivitas siswa dan guru berupa data hasil observasi, sedangkan pendekatan kuantitatif yaitu data yang diperoleh dari hasil tes yang diberikan kepada siswa."

Jenis penelitian yang digunakan dalam penelitian ini adalah Penelitian Tindakan Kelas (PTK). Menurut Suharsimi (2011:3) "Penelitian Tindakan Kelas adalah suatu perencanaan terhadap kegiatan belajar berupa sebuah tindakan yang sengaja dimunculkan dan terjadi dalam sebuah kelas secara bersama."

Penelitian ini dilaksanakan pada semester I, bulan Juli-Desember tahun pelajaran 2017/2018. Lama penelitian mulai dari tahapan perencanaan sampai tahapan pelaporan adalah selama \pm 6 bulan, terhitung dari waktu perencanaan sampai penelitian dimana penelitian ini dilaksanakan dalam 2 siklus. Siklus I dilaksanakan 2 kali pertemuan dan siklus II dilaksanakan 1 kali pertemuan. Siklus I pertemuan I dilaksanakan pada hari Selasa tanggal 18 Juli 2017, siklus I pertemuan II dilaksanakan pada hari Selasa tanggal 25 Juli 2017, dan siklus II dilaksanakan pada hari Selasa tanggal 01 Agustus 2017.

Jenis data dalam penelitian ini berupa hasil pengamatan, dokumentasi, dan tes dari setiap tindakan perbaikan pembelajaran dengan model pembelajaran kooperatif tipe STAD. Data penelitian berupa informasi tentang rencana pelaksanaan 
pembelajaran $\mathrm{PKn}$, pelaksanaan pembelajaran $\mathrm{PKn}$, dan peningkatan hasil belajar PKn. Sumber data dalam penelitian ini adalah proses pembelajaran PKn dengan model kooperatif tipe STAD. Data-data yang diperoleh adalah hasil pengamatan yang dilakukan selama proses pembelajaran berlangsung yang terdiri dari pelaksanaan pembelajaran dan evaluasi pembelajaran yang menggunakan format untuk mencatat berbagai aspek dari guru dan siswa.

Teknik pengumpulan data dalam penelitian ini dikumpulkan dengan menggunakan observasi, tes, dan dokumentasi sebagai pendukung. Observasi dilakukan untuk mengamati kondisi kelas tempat berlangsungnya pembelajaran PKn dengan model pembelajaran kooperatif tipe STAD. Observer bertugas mengamati apa yang terjadi pada proses pembelajaran. Dengan berpedoman pada lembaran observasi, observer mengamati apa yang terjadi selama pembelajaran. Unsur-unsur yang menjadi sasaran pengamatan dalam proses pembelajaran ditandai dengan memberikan ceklis pada kolom yang ada pada lembaran observasi. Tes yaitu untuk memperkuat data observasi yang terjadi dalam kelas terutama pada butir penguasaan materi pembelajaran dari unsur siswa, dan dokumentasi berupa pengambilan foto saat proses pembelajaran berlangsung.

Instrumen penelitian dalam penelitian ini berupa lembar penilaian RPP, lembar observasi, dan hasil tes. Lembar observasi pada dasarnya berisi deskripsi atau berupa paparan tentang latar pengamatan terhadap tindakan guru dan siswa sewaktu mengamati apa yang terjadi dalam proses pembelajaran PKn dengan menggunakan model kooperatif tipe STAD. Lembar tes terdiri dari beberapa butir soal yang disusun sesuai dengan indikator dan tujuan pembelajaran yang telah ditetapkan, dan dokumentasi menghasilkan sebuah foto kegiatan selama pelaksanaan pembelajaran.

Data penelitian ini dianalisis dengan menggunakan analisis data kualitatif dan kuantitatif. Model analisis data kualitatif yaitu analisa data yang dimulai dengan menelaah data sejak pengumpulan data sampai seluruh data terkumpul. Untuk hasil belajar digunakan analisis data kuantitatif yang digunakan untuk menganalisa data yang diperoleh dari nilai evaluasi siswa pada setiap siklus. Teknik analisa data 
kuantitatif digunakan untuk menganalisa hasil belajar siswa dalam bentuk persentase. Menurut Purwanto (2010:102) cara menghitung nilai tes tertulis dapat dilakukan dengan cara memberi skor setiap soal sesuai bobot soal, dengan menggunakan rumus:

$$
\mathrm{NP}=\frac{R}{S M} \times 100
$$

Keterangan:

$\mathrm{NP} \quad$ : Nilai persen yang dicari atau diharapkan

$\mathrm{R} \quad$ : Skor mentah yang diperoleh siswa

SM : Skor maksimum ideal dari tes yang bersangkutan

100 : Bilangan tetap

Kriteria taraf keberhasilan atau kualitatif Purwanto (2010:103):

$86-100 \%$ = Sangat Baik (A)

$76-85 \%=$ Baik (B)

$60-75 \%=$ Cukup $(\mathrm{C})$

$55-59 \%=$ Kurang $(\mathrm{K})$

$\leq 54 \% \quad=$ Kurang Sekali (TL)

\section{HASIL}

\section{Siklus I}

Penelitian siklus I dilaksanakan 2 kali pertemuan, pertemuan I dilaksanakan pada hari Selasa tanggal 18 Juli 2017 di SD Pembangunan Laboratorium UNP Kota Padang, dan pertemuan II dilaksanakan pada hari Selasa tanggal 25 Juli 2017 di SD Pembangunan Laboratorium UNP Kota Padang. Penelitian dilaksanakan sesuai dengan alur yang telah dibuat yaitu: (1) perencanaan, (2) pelaksanaan, (3) pengamatan, dan (4) refleksi. Hal tersebut dapat dideskripsikan sebagai berikut:

\section{Perencanaan}

Penggunaan model pembelajaran kooperatif tipe STAD dalam mata pelajaran PKn diwujudkan dalam bentuk RPP yang didalamnya terdapat 6 langkah-langkah model pembelajaran kooperatif tipe STAD. RPP ini disusun berdasarkan program semester I sesuai dengan waktu penelitian berlangsung. Materi yang diambil untuk 
siklus I pertemuan I adalah tentang menjelaskan pengertian Negara Kesatuan Republik Indonesia. Materi diambil berdasarkan SK yang ada pada KTSP 2006 mata pelajaran PKn kelas V semester I yaitu memahami pentingnya keutuhan NKRI, sedangkan KD yang diambil yaitu mendeskripsikan NKRI. Indikator dari pembelajaran ini adalah: (a) Menjelaskan pengertian NKRI, (b) menyebutkan letak lintang dan bujur NKRI, (c) menunjukkan sisi utara, selatan, timur dan barat NKRI, (d) membuat klipping tentang NKRI. Sedangkan materi yang diambil untuk siklus I pertemuan II adalah tentang menjelaskan wilayah NKRI, dengan indikator pembelajaran: (a) Menjelaskan wilayah NKRI, (b) menyebutkan nama provinsi dan ibukota yang termasuk dalam wilayah NKRI, (c) menunjukkan provinsi-provinsi yang menjadi wilayah NKRI pada awal kemerdekaan.

Sebelum pelaksanaan pembelajaran dimulai terlebih dahulu peneliti mempersiapkan RPP, LDK, lembar kunci jawaban yang akan digunakan dalam diskusi kelompok, lembar tes individu beserta kunci jawaban tes individu yang akan digunakan dalam pelaksanaan pembelajaran. Disamping itu peneliti juga mempersiapkan lembar pengamatan yang diberikan kepada observer untuk mengamati jalannya proses pembelajaran. Untuk menyampaikan materi peneliti juga mempersiapkan gambar peta Indonesia. Proses pembelajaran yang dirancang terdiri dari kegiatan awal, kegiatan inti, dan kegiatan akhir.

\section{Pelaksanaan}

Siklus I pertemuan I dilaksanakan pada hari selasa tanggal 18 Juli 2017 di SD Pembangunan Laboratorium UNP Kota Padang. Siklus I pertemuan II dilaksanakan pada hari Selasa tanggal 25 Juli 2017 di SD Pembangunan Laboratorium UNP Kota Padang.

Pelaksanaan pembelajaran diawali dengan memasuki kelas dan mengucapkan salam, mengkondisikan kelas, meminta ketua kelas menyiapkan dan memimpin teman-temannya untuk berdo'a, berdo'a bersama dan mencek kehadiran siswa. Kegiatan selanjutnya melakukan apersepsi untuk membuka skemata siswa terhadap 
materi yang akan dipelajari dan menyampaikan tujuan pembelajaran yang akan dicapai. Setelah itu peneliti melanjutkan pada kegiatan inti.

Langkah 1, peneliti menyampaikan materi yang akan dipelajari, penyajian materi di awali dengan memajang gambar peta Indonesia, peneliti memotivasi dan mengajak siswa untuk memperhatikan dan mengamati gambar yang telah dipajang peneliti. Kemudian peneliti menjelaskan tentang deskripsi negara Indonesia yang dapat dilihat di dalam peta Indonesia yang di pajang peneliti.

Langkah 2, peneliti membagi siswa ke dalam 4 kelompok kooperatif, yang tiap-tiap kelompok terdiri dari 5 orang siswa. Peneliti membagi kelompok tersebut secara heterogen dan meminta siswa untuk duduk di dalam kelompok yang telah dibagi, setelah siswa duduk dalam kelompoknya masing-masing kegiatan selanjutnya peneliti membagikan LDK dan teks bacaan yang sama pada masing-masing kelompok. Setiap kelompok mendiskusikan LDK nya, dan peneliti terus mengontrol dan membimbing siswa.

Langkah 3, peneliti menugasi perwakilan setiap kelompok untuk melaporkan hasil diskusi kelompoknya secara bergantian, dan kelompok yang lain memberikan tanggapan terhadap kelompok yang tampil. Setelah semua kelompok selesai, peneliti membagikan kunci jawaban LDK dan menugasi siswa untuk mencocokkan jawabannya dengan kunci LDK yang dibagikan. Setelah itu peneliti memberikan penilaian terhadap LDK yang telah dikerjakan siswa.

Langkah 4, peneliti menugasi semua siswa untuk kembali ke tempat duduk masing-masing. Setelah semua siswa kembali ke tempat duduknya masing-masing dan duduk dengan rapi, peneliti mengadakan tes individual untuk mengetahui tingkat pemahaman siswa terhadap materi yang dipelajari. Peneliti membagikan soal-soal tes kepada masing-masing siswa, siswa bekerja sendiri-sendiri dan peneliti mengawasi siswa saat mengerjakan soal-soal tes.

Langkah 5, peneliti memeriksa hasil tes yang telah dikumpulkan siswa, setelah diperoleh hasil tes, peneliti memasukkan nilai tersebut ke dalam skor peningkatan individual untuk selanjutnya dimasukkan ke dalam skor kelompok, 
kemudian skor peningkatan digunakan untuk menghitung poin perkembangan yang diperoleh masing-masing siswa.

Langkah 6, setelah diperoleh poin perkembangan pada masing-masing siswa, maka poin perkembangan tersebut dimasukkan ke dalam lembar ikhtiar kelompok, dan masing-masing kelompok akan mendapatkan penghargaan sesuai dengan kriteria poin perkembangan yang telah ditentukan.

Kegiatan yang dilakukan pada akhir pembelajaran yaitu membimbing siswa untuk menyimpulkan materi pembelajaran, dengan cara mengajukan pertanyaanpertanyaan, jawaban atas pertanyaan itu dipertegas dan diluruskan oleh peneliti, setelah itu siswa mencatat simpulan-simpulan dari materi yang telah dipelajari.

\section{Pengamatan}

Hasil pengamatan terhadap siklus I dilakukan terhadap RPP, aspek guru, aspek siswa, dan hasil belajar siswa baik pada pertemuan I maupun pertemuan II. Berikut ini hasil pengamatan terhadap ke 4 aspek tersebut pada siklus I, RPP memperoleh nilai $64,28 \%$ pada pertemuan I dan $82,14 \%$ pada pertemuan II, dengan rata-rata perolehan RPP untuk siklus I adalah 73,21. Pengamatan aspek guru memperoleh nilai 58,33\% pada pertemuan I dan 79,16\% pada pertemuan II, dengan rata-rata aspek guru pada siklus I 68,74. Pengamatan aspek siswa memperoleh hasil $58,33 \%$ pada pertemuan I dan $79,16 \%$ pada pertemuan II, dengan rata-rata aspek siswa pada siklus I adalah 68,74. Dan pengamatan hasil belajar siswa pada aspek kognitif memperoleh nilai 70\%. Pada aspek afektif memperoleh nilai 34,99\%, dan pada aspek psikomotor memperoleh nilai 31,66\% pada pertemuan I dan pada pertemuan II memperoleh nilai pada aspek kognitif $82,55 \%$ pada aspek afektif memperoleh nilai $86,66 \%$, dan pada aspek psikomotor memperoleh nilai $84,16 \%$, maka rata-rata hasil belajar aspek kognitif siswa pada siklus I adalah 76,12, rata-rata aspek afektif adalah 60,82\%, dan rata-rata aspek psikomotor adalah 57,91.

\section{Refleksi}

Berdasarkan hasil observasi dan hasil tes yang telah dilakukan maka dapat direfleksikan bahwa perencanaan, pelaksanaan, pengamatan, dan hasil belajar siswa 
dengan menggunakan model kooperatif tipe STAD belum terlaksana dengan maksimal. Selain itu hasil belajar siswa juga belum mencapai kategori keberhasilan yang diharapkan. dengan demikian penelitian ini dilanjutkan ke siklus II, dengan harapan hasilnya dapat lebih baik dari siklus I dan mencapai kategori keberhasilan sesuai dengan yang diharapkan, segala kekurangan yang terjadi pada siklus I akan diperbaiki pada siklus II.

\section{SIKLUS II}

Pada siklus II ini penelitian hanya dilakukan 1 kali pertemuan. Siklus II ini dilaksanakan pada hari Selasa tanggal 01 Agustus 2017 di SD Pembangunan Laboratorium UNP Kota Padang. Penelitian pada siklus II ini masih sama dengan penelitian pada siklus I, yaitu dimulai dari: (1) Perencanaan, (2) pelaksanaan, (3) pengamatan, dan (4) refleksi. Hal tersebut dapat dideskripsikan sebagai berikut:

\section{Perencanaan}

Pembelajaran siklus II dilaksanakan agar siswa lebih memahami pentingnya keutuhan NKRI dengan menggunakan model kooperatif tipe STAD. Adapun indikator pada siklus II ini yaitu: (1) Menjelaskan pembagian wilayah NKRI, (2) menanggapi makna dari NKRI, (3) membuat gambar peta Indonesia.

\section{Pelaksanaan}

Siklus II dilaksanakan hari Selasa tanggal 01 Agustus 2017 di SD Pembangunan Laboratorium UNP Kota Padang. Pelaksanaan diawali dengan mempersiapkan segala sesuatu yang diperlukan dalam proses pembelajaran, seperti kelengkapan RPP, kelengkapan LDK, teks bacaan, soal tes, kunci jawaban LDK, kunci jawaban soal tes, dan media yang digunakan. Kemudian peneliti meminta siswa untuk merapikan tempat duduknya masing-masing, meminta ketua kelas menyiapkan teman-temannya dan memimpin untuk berdo'a, berdo'a bersama dan mencek kehadiran siswa. Kemudian peneliti melakukan tanya jawab dan menyampaikan tujuan pembelajaran yang akan dicapai, selanjutnya masuk ke kegiatan inti dengan langkah-langkah kooperatif tipe STAD. 
Langkah 1, peneliti memulai dengan memajangkan gambar peta Indonesia di depan kelas, kemudian peneliti meminta siswa untuk memperhatikan gambar yang telah dipajang, melakukan tanya jawab tentang gambar, setelah itu peneliti mulai menerangkan materi pembelajaran.

Langkah 2, peneliti meminta siswa untuk duduk di dalam kelompok yang telah di bagi, setelah siswa duduk di dalam kelompoknya masing-masing, peneliti membagikan LDK dan teks bacaan yang sama kepada masing-masing kelompok. Setelah itu siswa mendiskusikan secara bersama-sama LDK yang telah dibagi peneliti dengan anggota kelompoknya, ketika siswa sedang berdiskusi peneliti membimbing dan memotivasi siswa.

Langkah 3, peneliti menugasi perwakilan setiap kelompok untuk melaporkan hasil diskusi kelompoknya, dan kelompok yang lain menanggapinya. Setelah setiap perwakilan kelompok melaporkan hasil diskusinya, peneliti membagikan kunci jawaban LDK, siswa kemudian mencocokkan jawabannya dengan kunci LDK yang telah dibagikan peneliti dan peneliti melakukan penilaian.

Langkah 4, siswa kembali ke tempat duduknya masing-masing untuk mengerjakan soal tes individual. Setelah semua siswa duduk di tempat duduknya masing-masing, peneliti membagikan soal tes individual, peneliti meminta siswa untuk mengerjakan soal tes sendiri-sendiri dengan waktu yang telah ditentukan. Saat siswa mengerjakan soal tes, peneliti mengawasi semua siswa.

Langkah 5, setelah waktu untuk mengerjakan soal tes selesai, siswa mengumpulkan soal dan lembar jawaban tesnya untuk segera diperiksa. Pada hasil tes siklus II ini sudah terlihat bahwa siswa sebagai subjek penelitian rata-rata sudah menguasai materi pembelajaran.

Langkah 6, setelah memperoleh hasil tes, maka peneliti menentukan skor peningkatan yang diperoleh siswa, kemudian skor peningkatan tersebut digunakan untuk menghitung poin perkembangan yang diperoleh masing-masing siswa. Kemudian poin perkembangan tersebut dimasukkan ke dalam lembar ikhtiar 
kelompok. Selanjutnya kelompok akan mendapatkan penghargaan sesuai dengan kriteria penghargaan kelompok.

Pada akhir pembelajaran peneliti mengarahkan dan membimbing siswa untuk menyimpulkan materi yang telah dipelajari dengan bertanya jawab, setiap jawaban akan dipertegas dan diluruskan oleh peneliti dan siswa mencatat kesimpulan materi pembelajaran.

\section{Pengamatan}

Sama seperti pada siklus I, pada siklus II ini juga dilakukan pengamatan tentang RPP, aspek guru, aspek siswa, dan hasil belajar siswa. Berikut ini adalah hasil pengamatan dari ke 4 aspek tersebut: (a) Pengamatan RPP pada siklus II ini memperoleh nilai 92,85\%, pengamatan aspek guru pada siklus II memperoleh nilai 91,66\%, pengamatan aspek siswa pada siklus II memperoleh nilai 91,66\%, dan pengamatan hasil belajar siswa pada siklus II pada aspek kognitif memperoleh nilai 93,5\%, pada aspek afektif memperoleh nilai 93,33\%, dan pada aspek psikomotor memperoleh nilai $94,58 \%$.

\section{Refleksi}

Berdasarkan hasil observasi dan hasil tes yang telah dilakukan, dapat direfleksikan bahwa perencanaan, pelaksanaan, dan hasil belajar siswa dengan menggunakan model kooperatif tipe STAD sudah terlaksana dengan baik dan hasil belajar siswapun sudah mencapai kategori keberhasilan yang diharapkan. dengan demikian penelitian dihentikan pada siklus II karena segala kekurangan-kekurangan yang muncul pada siklus I sudah berhasil di perbaiki pada siklus II.

\section{PEMBAHASAN}

\section{Siklus I}

\section{Perencanaan}

Perencaan sangat diperlukan dalam melakukan setiap kegiatan pembelajaran, agar tujuan pembelajaran dapat tercapai seperti apa yang diharapkan dan tidak 
menyimpang dari tujuan pembelajaran. Perencanaan yang dimaksud adalah Rencana Pelaksanaan Pembelajaran (RPP).

Pada RPP siklus I peneliti belum optimal dalam membuat RPP, hal ini terbukti dari hasil pengamatan RPP dari 28 skor maksimal hanya memperoleh 18 skor pada pertemuan I dan 23 skor yang diperoleh pada pertemuan II dengan rata-rata persentase yang diperoleh hanya 73,21\%. Pada RPP siklus I peneliti belum optimal dalam membuat RPP, sehingga kriteria yang didapatkan belum sesuai dengan apa yang diharapkan, maka dari itu penelitian belum dihentikan sampai disini, penelitian akan dilanjutkan ke siklus II.

\section{Pelaksanaan}

Pelaksanaan pembelajaran pada siklus I disajikan dalam 2 kali pertemuan. Setiap pertemuan dilaksanakan selama 2 jam pelajaran. Berdasarkan diskusi peneliti dengan guru kelas V SD Pembangunan Laboratorium UNP Kota Padang selama pelaksanaan pembelajaran PKn menggunakan model kooperatif tipe STAD di temukan hal-hal sebagai berikut: (1) Pada saat pembagian kelompok kelas sangat ribut, karena ada siswa yang tidak mau bergabung dengan kelompok yang telah dibagi oleh peneliti, (2) pada saat diskusi kelompok, siswa tidak aktif di dalam kelompoknya, mereka masih banyak yang diam, berpikir sendiri, dan kurang tertarik untuk berbagi ide atau pendapat dengan teman satu kelompoknya, (3) masih ada siswa yang tidak mau mengerjakan LDK kelompok bersama anggota kelompoknya, dan (4) peneliti belum optimal membimbing siswa dalam berdiskusi.

Berdasarkan hasil pengamatan aspek guru pada siklus I pertemuan I diperoleh skor 14 dari 24 skor maksimal dengan persentase 58,33\%, pada siklus I pertemuan II diperoleh skor 19 dari 24 skor maksimal dengan persentase 79,16\% dengan kualifikasi cukup. Pada aspek siswa siklus I pertemuan I memperoleh skor 14 dari 24 skor maksimal dengan persentase 58,33\% dengan kualifikasi kurang, pada siklus I pertemuan II memperoleh skor 19 dari 24 skor maksimal dengan persentase $79,16 \%$ dengan kualifikasi baik. Maka dari itu penelitian akan dilanjutkan ke siklus II, upaya perbaikan atas kekurangan-kekurangan di atas akan diperbaiki pada siklus II. 


\section{Hasil belajar}

Setelah pelaksanaan pembelajaran PKn menggunakan model kooperatif tipe STAD dilakukan maka diperoleh hasil belajar siswa. Hasil belajar ini terdiri dari tiga ranah yaitu ranah kognitif, ranah afektif, dan ranah psikomotor.

Berdasarkan analisis data pengamatan hasil belajar siswa pada siklus I pertemuan I diperoleh rata-rata hasil kognitif siswa 70\%, hasil afektif 34,99\%, dan hasil psikomotor $31,66 \%$. Selanjutnya dari analisis data pada pengamatan hasil belajar siswa siklus I pertemuan II diperoleh hasil rata-rata kognitif 82,25\%, hasil afektif $86,66 \%$, dan hasil psikomotor $84,16 \%$. Maka diperoleh rata-rata hasil belajar siswa pada siklus I, pada ranah kognitif 76,12, pada ranah afektif 60,82, dan ranah psikomotor 57,91. Hal ini menandakan hasil belajar siswa belum tercapai sesuai dengan yang diharapkan yaitu lebih dari $80 \%$. Untuk itu penelitian dilanjutkan ke siklus II.

\section{Siklus II}

\section{Perencanaan}

Pada siklus II RPP lebih disempurnakan lagi, peneliti lebih mempersiapkan rencana pembelajaran dengan lebih baik lagi.

Di dalam RPP siklus II ini rencana pembelajaran juga dibagi menjadi tiga tahap, yaitu kegiatan awal, kegiatan inti, dan kegiatan akhir. Dan pada RPP siklus II ini dari 28 skor maksimal peneliti sudah memperoleh 26 skor dengan persentase 92,85\%. Maka dari itu RPP yang dirancang pada siklus II sudah sesuai dengan kriteria keberhasilan yang diharapkan. Disini terlihat peneliti telah berhasil membuat

perencanaan pembelajaran dengan baik, peneliti sudah benar-benar mempersiapkan rencana pembelajaran terlebih dahulu sebelum melaksanakan pembelajaran.

\section{Pelaksanaan}

Pelaksanaan pembelajaran pada siklus II dilaksanakan selama 2 jam pelajaran, berdasarkan diskusi peneliti dengan guru kelas V SD Pembangunan Laboratorium UNP Kota Padang pada siklus II ini pembelajaran sudah terlaksana dengan baik, 
siswa sudah termotivasi dan bersemangat dalam belajar, dan siswa juga sudah terbiasa belajar secara berkelompok, hal ini sudah menunjukkan adanya peningkatan.

Dari hasil pengamatan aspek guru pada siklus II memperoleh skor 22 dari 24 skor maksimal dengan persentase 91,66\% dengan kualifikasi sangat baik dan pada aspek siswa memperoleh skor 22 dari 24 skor maksimal dengan persentase 91,66\% dengan kualifikasi sangat baik. hal ini membuktikan bahwa sudah ada peningkatan, berarti upaya peningkatan yang dilakukan pada siklus II telah berhasil sesuai dengan apa yang diharapkan.

\section{Hasil belajar}

Pada perbaikan pembelajaran pada siklus II telah membuahkan hasil, hasil yang diperoleh telah sesuai dengan apa yang diharapkan. hal itu terlihat pada analisis data pengamatan hasil belajar siswa pada siklus II, pada siklus II diperoleh nilai ratarata hasil belajar kognitif 93,5\%, rata-rata hasil belajar afektif 93,33\%, dan rata-rata hasil belajar psikomotor 94,58\%. Maka dari itu dapat disimpulkan bahwa hasil belajar siswa pada pembelajaran PKn menggunakan model kooperatif tipe STAD di SD Pembangunan Laboratorium UNP Kota Padang telah tercapai sesuai dengan kriteria yang telah ditetapkan yaitu $80 \%$, hal ini berarti penelitian berhenti pada siklus II dan tidak dilanjutkan pada siklus berikutnya.

\section{SIMPULAN DAN SARAN}

Berdasarkan data hasil penelitian dan pembahasan tentang upaya peningkatan pembelajaran PKn menggunakan model kooperatif tipe STAD maka dapat disimpulkan bahwa rencana pelaksanaan pembelajaran PKn di kelas V SD menggunakan model STAD sudah terlaksana dengan baik, hal ini dapat dilihat dari peningkatan nilai RPP dari siklus I yaitu 76,12\% kategori baik meningkat menjadi 93,5\% dengan kategori sangat baik pada siklus II. Selanjutnya pelaksanaan pembelajaranpun juga terlaksana sesuai dengan kegiatan yang telah direncanakan, hal ini dapat dilihat dari adanya peningkatan asprk guru dari 68,74\% kategori cukup pada siklus I meningkat menjadi 91,66\% kategori sangat baik pada siklus II dan pada 
aspek siswa pada siklus I dari 68,74\% kategori cukup meningkat menjadi 91,66\% kategori sangat baik pada siklus II. Dan pada hasil belajar siswapun juga telah mengalami peningkatan, hal ini juga dapat dilihat dari nilai rata-rata yang diperoleh pada siklus I yaitu 76,12 dengan kategori baik mengalami peningkatan pada siklus II menjadi 93,5 dengan kategori sangat baik.

Berdasarkan kesimpulan di atas maka dapat disarankan hal-hal berikut ini: pembelajaran PKn menggunakan model kooperatif tipe STAD layak dipertimbangkan oleh guru untuk menjadi pembelajaran alternatif yang dapat digunakan dalam pembelajaran, karena berdasarkan penelitian yang telah dilakukan model kooperatif tipe STAD ini dapat meningkatkan hasil belajar siswa, bagi guru sebelum memulai pembelajaran terlebih dahulu harus menyusun perencanaan pembelajaran dengan sebaik-baiknya, karena pembelajaran yang baik akan dapat terlaksana dengan adanya perencanaan yang baik terlebih dahulu, dan guru harus kreatif dalam merancang pembelajaran, guru perlu memberikan perhatian, bimbingan, dan motivasi belajar yang baik kepada seluruh siswa.

\section{DAFTAR RUJUKAN}

Arma Mariangke, dkk. Jurnal Kreatif Tadulako Online Vol. 3 No. 4 ISSN 2354614X. Meningkatkan Hasil Belajar Siswa Dengan Menggunakan Model Kooperatif Tipe STAD Pada Mata Pelajaran PKn di SDK Lengaruh.

Depdiknas. 2006. Kurikulum Tingkat Satuan Pendidikan Jenjang Pendidikan Dasar. Jakarta: Depdiknas.

Dr. Purwanto, M. Pd. 2010. Evaluasi Hasil Belajar. Jakarta: Pustaka Belajar.

Dr. Rusman, M. Pd. 2011. Model-Model Pembelajaran: Mengembangkan Profesionalisme Guru. Jakarta: Rajawali Pers.

Mohammad Said, dkk. 2013. Jurnal Kreatif Tadulako Online Vol. 4 No. 3 ISSN 2354-614X. Meningkatkan Hasil Belajar Siswa pada Pembelajaran PKn dengan Menggunakan Model Pembelajaran Kooperatif STAD di Kelas IV SDN 2 Siney. 
Asma Nur, 2008. Model Pembelajaran Kooperatif. Padang: Universitas Negeri Padang Press.

Prof. Arikunto Suharsimi, dkk. 2011. Penelitian Tindakan Kelas. Jakarta: PT. Bumi Aksara. 